\title{
RANCANGAN SISTEM ADMINISTRASI AKADEMIK BERBASIS KOMPUTER
}

\author{
${ }^{1 *}$ Supriyanto \\ ${ }^{2 *}$ Rahmat Hidayat \\ ${ }^{1,2 *}$ STIM Sukma Medan \\ Jln. Laksana No. 58 E-F Medan
}

\begin{abstract}
This study aims to determine how the implementation of the system design of computer-based academic administration and knows the system design, computer-based academic administration can create convenience and speed for the various parties to access the data. This study used methods include: (1) Method of data collection, which includes collection of documents and the making of an application program using VisualBasic with the MySQL database to handle the input, process and desired output, (2) System Design Methods, (3) Testing Method system, and (4) Implementation Method. The results showed that the design of academic administration system that made a relationship between tables that have a relation to one another, with a system of computer-based academic administration will ease the process of academic activities organized, so that academic activities can be run effectively and efficiently and what is planned can be run in accordance with a predetermined time.
\end{abstract}

Keywords *: System Academic Administration

\section{Pendahuluan}

Perkembangan dunia teknologi komputer dewasa ini sangat pesat, kebutuhan akan komputer merupakan hal yang utama sebagai penunjang kegiatan pekerjaan atau membantu menyelesaikan tugas-tugas. Peranan komputer saat ini banyak dipergunakan untuk keperluan pengolahan data baik data dalam jumlah kecil maupun dalam jumlah yang besar. Data yang sudah diolah di dalam komputer tersebut akan menghasilkan administrasi yang cepat dan akurat. Kegiatan yang paling menonjol dalam suatu pendidikan tinggi adalah pengolahan informasi yang tersedia yang berkaitan dengan kegiatan yang ada di dalam pendidikan tersebut, mulai dari pengelolaan administrasi mahasiswa sampai pengelolaan akademisnya.

Dalam proses penyelenggaraan kegiatan akademik, dituntut adanya suatu kecepatan dan keakuratan dalam pengolahan data mahasiswa. Pengolahan data tersebut antara lain berupa pembuatan Daftar Nilai Studi, Kartu Rencana Studi. Dalam pemrosesan ini sering dijumpai adanya kendalakendala seperti keterlambatan mahasiswa dalam mengisi Kartu Rencana Studi, sulitnya mengontrol mata kuliah yang diambil mahasiswa, sehingga pemberian data/informasi pada bagian lain menjadi tidak sempurna. Ketidakakuratan data mengakibatkan pekerjaan lain juga terganggu, misalnya pembuatan Kartu Hasil Studi yang mengalami keterlambatan.

Pada umumnya hal yang sering terjadi pada perguruan tinggi adalah keterbatasan pengolahan data, khsusnya sistem administrasi akademik. Sebelum adanya komputer pengelolaan sistem administrasi akademik di perguruan tinggi diolah secara manual, proses ini akan memerlukan waktu yang cukup lama dan sering mengakibatkan kesalahan yang diakibatkan oleh manusia itu sendiri, sehingga kegiatan akademik pun akan terganggu. Dengan adanya komputer akan menghemat waktu, biaya dan efisien kerja akan bisa dicapai.

Rancangan sistem administrasi akademik dibangun untuk memudahkan struktur pengelolaan data, sehingga data-data administrasi akademik seperti : data dosen, data mahasiswa, kurikulum, absensi, KRS, KHS, absen ujian (UTS/UAS) dan transkrip nilai dapat diolah secara cepat dan akurat serta menciptakan kemudahan dan kecepatan bagi pihak-pihak terkait dalam mengakses data yang dibutuhkan. Berdasarkan uraian di atas, maka penelitian 
memberikan rumusan masalah sebagai berikut; (a) Bagaimana rancangan sistem administrasi akademik berbasis komputer dilaksanakan, (b) Apakah rancangan sistem administrasi akademik berbasis komputer menciptakan kemudahan dan kecepatan bagi berbagai pihak dalam mengakses data.

Untuk mendapatkan data dari penelitian yang akan dilakukan, maka perlu ditetapkan arah dan tujuan dari penelitian ini. Adapun tujuannya dapat dirumuskan sebagai berikut; (a) untuk mengetahui bagaimana pelaksanaan rancangan sistem administrasi akademik berbasis komputer, (b) untuk mengetahui rancangan sistem administrasi akademik berbasis komputer menciptakan kemudahan dan kecepatan bagi berbagai pihak dalam mengakses data.

\section{Bahan dan Metode}

Penelitian ini mneggunakan metode antara lain: (1) Metode Pengumpulan data, yang meliputi Pengumpulan dokumen dan pembuatan program aplikasi VisualBasic dengan menggunakan database MySQL untuk penanganan input, proses dan output yang diinginkan, (2) Metode Perancangan Sistem, (3) Metode Uji Coba Sistem, dan (4) Metode Implementasi.

\section{Hasil dan Pembahasan}

Dalam mendefinisikan pengertian dari sistem ada dua kelompok pendekatan yaitu menekankan pada prosedurnya dan menekankan pada komponen elemennya. Pendekatan sistem yang lebih menekankan pada prosedurnya mendefinisikan sistem adalah suatu jaringan kerja dari prosedur-prosedur yang saling berhubungan berkumpul bersama-sama untuk melakukan suatu kegiatan atau untuk menyelesaikan suatu masalah. (Jogiyanto, 2001). Sistem itu adalah suatu kumpulan atau variabel yang terorganisasi, saling berinteraksi, saling bergantung satu sama lain dan terpadu.

Richard F. Nevchel dalam bukunya, Management by Sistem mendefinisikan pendekatan sistem yang merupakan jaringan kerja dari prosedur (procedure) adalah suatu operasi tulis menulis, biasanya melibatkan beberapa bagian di dalam satu atau lebih departemen yang diterapkan untuk menjamin penanganan yang seragam ditransaksi bisns yang berlaku. Karakteristik sistem dibagi menjadi :

a. Komponen Sistem : Sistem terdiri dari sejumlah komponen yang saling berinteraksi, yang artinya saling bekerja sama membentuk satu kesatuan, dapat berupa suatu sub sistem atau bagian-bagian sistem.

b. Batas Sistem : Merupakan daerah yang membatasi antara suatu sistem dengan sistem yang lain atau dengan sistem luar sebagai kesatuan yang menunjukkan ruang lingkup sistem tersebut.

c. Lingkungan Luar Sistem : Apapun di luar batas sistem yang dapat mempengaruhi operasi sistem, bersifat menguntungkan dan merugikan.

d. Penghubung Sistem : (Interface) media penghubung antara sub sistem dengan sistem yang lain, memungkinkan suatu sub sistem dapat berinteraksi dengan sub sistem yang lain untuk membentuk satu kesatuan.

e. Masukan Sistem : Masukan (input) adalah energi yang dimasukkan ke dalam sistem dapat berupa, masukan perawatan (maintenance input) dan masukan sinyal (sinyal input).

f. Keluaran Sistem : Hasil yang diolah dan diklasifikasikan menjadi keluaran yang berguna dan sisa pembuangan pengolahan sistem, suatu sistem mempunyai bagian pengolahan yang akan merubah masukan menjadi keluaran.

g. Sasaran Sistem : Suatu sistem mempunyai tujuan (goal) atau sasaran (objective) kalau tidak sistem tidak akan ada gunanya.

Sebuah sistem yang baik terdiri dari sistem-sistem dan bagian sub sistem yang masingmasing sub sistem terdiri dari subsistem-subsistem yang lebih kecil lagi atau terdiri dari komponen-komponen subsistem yang saling berinteraksi dan saling berhubungan membentuk satu kesatuan sehingga pada akhirnya tujuan dari sistem tersebut tercapai. 
1. Kriteria sistem yang baik, (a) Kegunaan, Sistem harus menghasilkan informasi yang tepat waktu dan relevan untuk proses pengambilan keputusan manajemen dan personel operasi di dalam organisasi, (b) Ekonomis, Semua bagian sistem termasuk laporan, pengawasan \& lain sebagainya harus menyumbangkan suatu nilai plus sekurang-kurangnya sebesar atau sesuai dengan biayanya, (c) Keandalan, Output sistem harus mempunyai tingkat ketelitian yang tinggi dan sistem itu sendiri harus mampu beroperasi secara efektif, efisiensi dan aman, (d) Kapasistas, Sistem harus mempunyai kapasitas memadai untuk menangani berbagai periode operasi sehingga operasi dapat berjalan dengan lancar dan mempunyai kapasitas yang cukup, (e) Kesederhanaan, Sistem harus mempunyai kesederhanaan yang cukup untuk menunjang operasi dan dapat mudah dimengerti dan prosedurnya mudah dimengerti, dan (f) Fleksibilitas, Sistem harus cukup fleksibel untuk menampung berbagai perubahan yang mungkin terjadi.

2. Elemen-elemen system, (a) Tujuan, Merupakan tujuan akhir atau sasaran dari pengolahan sistem tersebut yang dapat berupa: Tujuan usaha, Kebutuhan, Masalah, dan Prosedur pencapaian tujuan, (b) Batasan, Merupakan daerah yang membatasi antara satu sistem dengan sistem yang lain atau dengan lingkungan luarnya sehingga memungkinkan suatu sistem dipandang sebagai satu kesatuan dalam sebuah ruang lingkup. Batasan-batasan yang ada dalam mencapai tujuan dari sistem dapat berupa: Peraturan, Biaya-biaya, Personel, Peralatan, dll, (c) Penghubung sistem, Penghubung merupakan suatu media yang menghubungkan antara subsistem yang satu dengan subsistem yang lainnya yang memungkinkan sumber daya mengalir dari subsistem satu ke subsistem yang lain, (d) Kontrol, Merupakan pengawasan dari pelaksanaan pencapaian tujuan sistem yang berupa: Asal Masukan, Frekuensi pemasukan data, Jenis pemasukan data. (e) Input, Merupakan bagian dari sistem yang bertugas untuk menerima data masukan, dimana data dapat berupa: Asal masukan, Frekuensi pemasukan data, Jenis pemasukan data. (f) Proses, Merupakan bagian yang memproses masukan data menjadi keluaran berupa informasi yang sesuai dengan keinginan penerima dan dapat berupa: Klasifikasi, Peringkasan, Pencaharian, dll, (g) Output, Merupakan keluaran atau tujuan akhir dari sistem yang dapat berupa: Laporan, Grafik, dll, (h) Umpan Balik, Umpan balik merupakan suatu reaksi yang dilakukan apabila mendapat suatu masukan dapat berupa: Perbaikan, Pemeliharaan, dll.

3. Tingkah laku sistem

Sebagai sesuatu yang dinamik, sebuah sistem memiliki tingkah laku yang berbeda dari satu sistem dengan sistem yang lain. Berdasarkan pola tingkah laku, terdapat 5 jenis sistem yaitu: (a) Deterministic Sistem, Adalah sistem dimana segala tingkah lakunya dapat diramalkan, (b) Probabilistic Sistem, Adalah sistem dimana segala tingkah lakunya tidak dapat diramalkan, (c) Closed Sistem, Adalah sistem yang tidak mempunyai relasi atau hubungan dengan lingkungan, dan (d) Open Sistem, Adalah sistem yang mempunyai relasi atau hubungan dengan lingkungan.

\section{Studi Kelayakan}

Pada bagian ini penulis memutuskan usaha-usaha penyusunan sistem yang akan dilakukan untuk menyelesaikan masalah-masalah sistem informasi. Laporan dari studi kelayakan menentukan beberapa perubahan, yang nantinya akan menyarankan untuk diadakan penelitian lebih mendalam atau memutuskan untuk segera dilaksanakan. Studi Kelayakan menyangkut berbagai aspek sistem baru yang diusulkan.

Langkah-langkah dalam studi kelayakan, antara permintaan penyusunan sistem dan hasil akhir studi kelayakan adalah:

a. Mengumpulkan fakta data-data, seperti; data dosen, data mahasiswa, kurikulum, KRS, KHS dan transkrip nila;

b. Mendefinisikan masalah-masalah aktifitas system administrasi akademik beserta entitientiti yang berhubungan; 
c. Menentukan kendala sistem yaitu kebutuhan akan jaringan antar komputer;

d. Menentukan kebutuhan informasi dari dosen dan pihakpihak yang terkait;

e. Mempelajari sistem dan prosedur penyusunan materi data di Sekolah Tinggi Ilmu Manajemen Sukma Medan;

f. Mengembangkan dan mengevaluasi alternatif pemecahan masalah;

g. Mengembangkan logical model dari sistem yang diusulkan

Setelah mengumpulkan fakta dan mendokumentasikannya kemudian memperhitungkan apakah organisasi sebaiknya melanjutkan untuk analisis sistem terstruktur dan memperhitungkan apakah tim penyusunan sistem dapat menyelesaikan masalah dalam waktu dan anggaran biaya yang masuk akal.

Adapun beberapa aspek yang perlu diperhatikan, yaitu:

1. Kelayakan Teknik, Kelayakan penyusunan sistem agar dapat menyelesaikan masalah dengan menggunakan hardware dan software yang tersedia.

a. Komputer Server :

$>$ Personal Komputer Pentium 4 (minimum) disarankan yang lebih tinggi

$>$ VGA Card $512 \mathrm{Mb}$ disarankan yang lebih tinggi

$>$ RAM Minimal 1 GB

$>$ Harddisk 100-160 GB

$>$ Sistem Operasi Windows

$>$ Bahasa Pemrograman Visual Basic

$>$ Database : MySql

$>$ LAN Card

b. Komputer Client:

$>$ Personal Komputer Pentium 4 (minimum) disarankan yang lebih tinggi

$>$ VGA Card $512 \mathrm{Mb}$ disarankan yang lebih tinggi

$>$ RAM Minimal 512

$>$ Harddisk 80-100 GB

$>$ Sistem Operasi Windows

$>$ Bahasa Pemrograman Visual Basic

$>$ Driver MySql

$>$ LAN Card

2. Kelayakan Operasi, Kelayakan menyelesaikan masalah tersebut dengan menggunakan personel yang terkait akan penjadwalan dan administrasi laboraturium.

3. Kelayakan Ekonomis, Kelayakan menyelesaikan masalah dan memperhitungkan keuntungan/kerugian serta efisiensi biaya operasional. Adanya Sistem informasi yang dapat mengorganisasikan penjadwalan guna menunjang proses belajar mengajar mahasiswa.

4. Kelayakan Jadwal, Kelayakan menyelesaikan masalah dalam hitungan waktu. Direncanakan dalam 1,5 bulan.

\section{Rancangan Kebutuhan Sistem}

Kebutuhan-kebutuhan sistem yang akan dikembangkan meliputi: input, output, operasi dan resources. Pada tahap penentuan kebutuhan sistem ini dilakukan evaluasi untuk mendapatkan keandalan sistem yang baru, sasaran utama pada tahap ini adalah mendefinisikan apa yang seharusnya dilakukan sistem baru dan kemudian menentukan kriteria yang dapat digunakan untuk mengevaluasi keandalan sistem baru. Antara lain: (a) Output-output yang harus dihasilkan, (b) Input-output yang diperlukan untuk menghasilkan output-output, (c) Operasi-operasi yang dilakukan untuk menghasilkan output-output

Untuk penggambaran konsep aliran data dari penentuan kebutuhan sistem, diperlukan diagram konteks, Data Flow Diagram dengan pendekatan dengan teknik Gane \& Sarson, flowchart kemudian dilanjutkan dengan desain database, relasi tabel, desain input Output. Setelah semuanya terpenuhi kemudian dilanjutkan ke tahap implementasi dan evaluasi. 


\section{Rancangan Sistem}

Rancangan sistem adalah merancang atau membuat sistem baru yang diterapkan untuk mengatasi masalah yang lama. Menurut Robert J. Nerselo dan Reutor dalam bukunya Data Processing System and Concept mengatakan tahap setelah analisis dari sirklus pengembangan sistem adalah: pendefinisian dari kebutuhan-kebutuhan fungsional dan persiapan untuk rancang bangun implementasi, penggambaran bagaimana sistem dibentuk.

John Bunch dan Gary Gruknisti dalam bukunya menyatakan perancangan sistem dapat didefinisikan sebagai penggambaran, perencanaan dan pembuatan sketsa atau pengaturan dari beberapa elemen yang terpisah kedalam satu kesatuan yang utuh dan berfungsi.

George M. Scooft dalam bukunya Principles of Management Sistem menentukan bagaimana suatu sistem akan menyelesaikan apa yang mesti diselesaikan, tahap ini menyangkut mengkonfigurasi dari komputer perangkat lunak dan perangkat keras dari suatu sistem, sehingga setelah instalasi dari sistem akan benar-benar memuaskan.

Perancangan sistem dapat diartikan sebagai tahap setelah analisis dari sirklus pengembangan sistem, pendefinisian dari kebutuhan-kebutuhan fungsionalis, persiapan untuk rancangan bangunan implementasi, menggambarkan bagaimana suatu sistem dibentuk (penggambaran, perencanaan, pembatasan sketsa) termasuk mengkonfigurasi komponenkomponen perangkat lunak dan perangkat keras dari suatu sistem

\section{Data Flow Diagram}

Dalam suatu perancangan untuk mempermudah penggambaran suatu sistemnya atau sistem yang akan dikembangkan, bagaimana data mengalir dan bagaimana data akan disimpan maka dipakailah yang namanya Diagram Arus Data (Data Flow Diagram = DFD). DFD merupakan model yang menggambarkan sistem sebagai jaringan kerja antar fungsi yang berhubungan satu sama lain dengan aliran dan penyimpanan data. Sebagai perangkat analisis, model ini hanya mampu memodelkan sistem dari satu sudut pandang yaitu sudut pandang fungsi. (Husni Iskandar Pohan dan Kusnassriyanto Saiful Bahri, 1997).

Data Flow Diagram adalah model logika data atau proses yang dibuat untuk menggambarkan darimana asal data dan kemana tujuan data yang keluar dari sistem, dimana data disimpan, proses apa yang menghasilkan data tersebut dan interaksi antara data yang tersimpan dan proses yang dikenakan pada data tersebut. DFD menggambarkan penyimpanan data dan proses yang mentranformasikan data. DFD menunjukkan hubungan antara data pada sistem dan proses pada sistem. (Andri Kristanto, 2004).

\section{Struktur Data}

Pada bagian ini akan dijelaskan satu persatu tentang struktur tabel yang digunakan dan merupakan satu kesatuan dalam struktur database, serta mengenai hubungan antar tabel dalam database yang bersangkutan.

* Tabel Master.dbf, Tabel ini merupakan tempat penyimpanan tabel master seperti master perguruan tinggi, master program studi, dan master kelas

\begin{tabular}{|l|l|l|l|}
\hline Nama Field & Tipe Data & Lebar Data & Kunci (Key) \\
\hline MasterPT & Character & 100 & \\
\hline MasterProdi & Character & 30 & \\
\hline MasterKelas & Character & 6 & \\
\hline
\end{tabular}

Tabel 1: Tabel Master.dbf

Keterangan:

MasterPT adalah msater yang berisi identitas perguruan tinggi, yang terdiri dari: nama perguruan tinggi, nama fakultas/program studi, dan alamat; 
MasterProdi adalah master yang berisi nama program studi dan jenjang studi;

MasterKelas adalah master yang berisi pembagian kelas berdasarkan program studi.

* Tabel MasterDosen.dbf, Tabel ini merupakan tempat penyimpanan data-data dosen yang mengampu matakuliah.

\begin{tabular}{|l|l|l|l|}
\hline Nama Field & Tipe Data & Lebar Data & Kunci (Key) \\
\hline KodeDosen & Numeric & 10 & Primary Key \\
\hline NamaDosen & Character & 30 & \\
\hline TempatLahir & Character & 30 & \\
\hline TglLahir & Numeric & 6 & \\
\hline Pendidikan & Character & 30 & \\
\hline Jafa & Character & 2 & \\
\hline
\end{tabular}

Tabel 2 : Tabel MasterDosen.dbf

Keterangan:

Kodedosen adalah kode dari dosen yang mengampu matakuliah;

> Namadosen adalah nama dosen yang mengampu matakuliah;

> TempatLahir adalah tempat dimana dosen tersebut dilahirkan;

$>$ TglLahir adalah tanggal kelahiran dari dosen tersebut dengan format dd-mm-yy;

$>$ Pendidikan adalah pendidikan dosen dari S1, S2, S3;

$>$ Jafa adalah jabatan fungsional akademik dosen yang meliputi, AA (Asisten Ahli), L (Lektor), LK (Lektor Kepala), GB (Guru Besar).

* Tabel DosenPA.dbf, Tabel ini merupakan daftar nama dosen penasehat akademik dengan pembagian mahasiswa berdasarkan kode kelas.

\begin{tabular}{|l|l|l|l|}
\hline Nama Field & Tipe Data & \multicolumn{1}{c|}{ Lebar Data } & Kunci (Key) \\
\hline KodeDosen & Numeric & 10 & Primary Key \\
\hline KodeKelas & Character & 5 & \\
\hline
\end{tabular}

Tabel 3 : Tabel DosenPA.dbf

* Tabel MasterMhs.dbf, Tabel ini merupakan tempat penyimpanan data-data mahasiswa yang terdaftar di akademik.

\begin{tabular}{|l|l|l|l|}
\hline Nama Field & Tipe Data & Lebar Data & Kunci (Key) \\
\hline NPM & Character & 12 & Primary Key \\
\hline Nama & Character & 30 & \\
\hline TempatLahir & Character & 30 & \\
\hline TglLahir & Numeric & 6 & \\
\hline StatusMhs & Character & 15 & \\
\hline ProgramStudi & Numeric & 1 & \\
\hline ProgramKul & Numeric & 1 & \\
\hline TahunAjar & Character & 6 & \\
\hline Jenjang & Character & 2 & \\
\hline KodeKelas & Character & $5(1$-kodeProdi-1) & \\
\hline
\end{tabular}

Tabel 4 : Tabel MasterMhs.dbf

Keterangan : 
NPM adalah Nomor Pokok Mahasiswa;

Nama adalah nama dari mahasiswa;

> TempatLahir adalah tempat dimana mahasiswa tersebut dilahirkan;

- TglLahir adalah tanggal kelahiran dari mahasiswa tersebut dengan format dd-mm-yy;

> StatusMhs adalah status mahasiswa pada saat masuk, mahasiswa baru atau pindahan;

$>$ ProgramStudi adalah Program Studi yang diambil yaitu Manajemen atau Manajemen Perusahaan;

ProgramKul adalah jenis perkuliahan yang diambil yaitu Reguler atau Paralel;

> TahunAjar adalah tahun ajaran atau tahun masuk dari mahasiswa yaitu 2009-1 untuk semester ganjil tahun ajaran 2009/2010;

> Jenjang adalah Strata Pendidikan yang diambil yaitu D3, S1;

> KodeKelas adalah kode dimana kelas mahasiswa berada misalnya: (1-kodeProdi-1) menyatakan mahasiswa berada pada semester 1 , program studi tertentu, banyaknya kelas.

* Tabel Kurikulum.dbf, Tabel ini tabel kumpulan mata kuliah dari semester 1 sampai dengan semester 8

\begin{tabular}{|l|l|l|l|}
\hline Nama Field & \multicolumn{1}{l}{ Tipe Data } & \multicolumn{1}{l|}{ Lebar Data } & \multicolumn{1}{l|}{ Kunci (Key) } \\
\hline Semester & Numeric & 1 & \\
\hline KodeMK & Character & 8 & \\
\hline NamaMK & Character & 30 & \\
\hline SKS & Numeric & 1 & \\
\hline JenisMK & Character & 10 & \\
\hline
\end{tabular}

Tabel 5 : Tabel Kurikulum.dbf

Keterangan :

$>$ Semester adalah tingkat semester yang sedang diambil mahasiswa yaitu 1, 2, 3, 4, 5, 6, 7, dan 8;

KodeMK adalah kode setiap mata kuliah yang mempunyai ciri unik setiap mata kuliah;

NamaMK adalah nama setiap mata kuliah;

SKS adalah bobot satuan kredit semester setiap mata kuliah.

* Tabel KRS.dbf, Tabel ini merupakan tabel penyimpanan rencana mata kuliah persemester yang diambil setiap mahasiswa.

\begin{tabular}{|l|l|l|l|}
\hline Nama Field & Tipe Data & Lebar Data & Kunci (Key) \\
\hline NPM & Numeric & 12 & Primary Key \\
\hline Nama & Character & 30 & \\
\hline ProgramStudi & Numeric & 1 & \\
\hline Jenjang & Character & 2 & \\
\hline TahunAjar & Character & 6 & \\
\hline Semester & Numeric & 1 & \\
\hline KodeKelas & Character & 6 & \\
\hline KodeMK & Character & 10 & \\
\hline NamaMK & Character & 30 & \\
\hline SKS & Numeric & 1 & \\
\hline KodeDosen & Numeric & 10 & \\
\hline
\end{tabular}

Tabel 6 : Tabel KRS.dbf 
Tabel KHS.dbf, Tabel ini merupakan tabel hasil evaluasi yang berisi nilai mata kuliah persemester yang diambil setiap mahasiswa

\begin{tabular}{|c|c|c|c|}
\hline Nama Field & Tipe Data & Lebar Data & Kunci (Key) \\
\hline NPM & Numeric & 12 & Primary Key \\
\hline Nama & Character & 30 & \\
\hline ProgramStudi & Numeric & 1 & \\
\hline Jenjang & Character & 2 & \\
\hline TahunAjar & Character & 6 & \\
\hline Semester & Numeric & 1 & \\
\hline KodeMK & Character & 10 & \\
\hline NamaMK & Character & 30 & \\
\hline SKS & Numeric & 1 & \\
\hline $\mathrm{HM}$ & Character & 1 & \\
\hline $\mathrm{AM}$ & Numeric & 1 & \\
\hline M & Numeric & 2 & \\
\hline Ket & Character & 10 & \\
\hline Jumlah & Numeric & 3 & \\
\hline IPS & Numeric & 4 & \\
\hline IPK & Numeric & 4 & \\
\hline MaxYAD & Numeric & 2 & \\
\hline Tanggal & DateTime & 8 & \\
\hline
\end{tabular}

Tabel 7 : Tabel KHS.dbf

Keterangan :

$>$ HM (Huruf mutu) adalah nilai mahasiswa yang dilambangkan dengan huruf, yaitu: A, $\mathrm{B}, \mathrm{C}, \mathrm{D}, \mathrm{E}$;

$\mathrm{AM}$ (Huruf mutu) adalah bobot nilai dari $\mathrm{HM}$ yaitu, $\mathrm{A}=4, \mathrm{~B}=3, \mathrm{C}=2, \mathrm{D}=1, \mathrm{E}=0, \mathrm{~T}=0$;

$>\mathrm{M}$ (mutu) adalah hasil perkalian antara bobot SKS dengan M (mutu);

$>$ Ket adalah keterangan apabila ada salah satu mata kuliah yang mendapat $\mathrm{T}$ maka Tunda;

$>$ Jumlah adalah penjumlahan bobot nilai SKS dan M (mutu);

$>$ IPS adalah indeks prestasi semester, hasil bagi antara jumlah mutu dengan jumlah SKS yang diambil pada semester berjalan;

> IPK adalah indeks prestasi kumulatif, hasil bagi antara jumlah mutu dengan jumlah SKS dari semester awal sampai semester akhir;

MaxYAD adalah jumlah maksimum SKS yang akan diambil pada semester berikutnya berdasarkan rentang nilai yang sudah ditetapkan;

Tanggal adalah tanggal pada saat mencetak KHS.

* Tabel AbsenUjian.dbf, Tabel ini merupakan tempat penyimpanan daftar nama mahasiswa per mata kuliah pada semester berjalan serta dosen pengampu.

\begin{tabular}{|l|l|l|l|}
\hline Nama Field & \multicolumn{1}{l}{ Tipe Data } & & \\
\hline NamaMK & KodeMK/Numeric & & \\
\hline SKS & Numeric & 1 & Foreign Key \\
\hline NamaDosen & KodeDosen/Numeric & 10 & \\
\hline
\end{tabular}




\begin{tabular}{|l|l|l|l|}
\hline ProgramStudi & Numeric & 1 & \\
\hline Semester & Numeric & 1 & \\
\hline TahunAjar & Character & 6 & \\
\hline NPM & Numeric & 12 & Foreign Key \\
\hline Nama & Character & 30 & \\
\hline TotNilai & Numeric & 2 & \\
\hline NilaiAbs & Character & 1 & \\
\hline TandaTangan & Character & 10 & \\
\hline
\end{tabular}

Tabel 8: Tabel AbsenUjian.dbf

Keterangan :

TotNilai adalah jumlah nilai akhir (numeric) yang diperoleh mahasiswa;

NilaiAbs adalah nilai character terhadap nilai akhir mahasiswa, yaitu A, B, C, D, E, dan $\mathrm{T}$;

TandaTangan adalah tanda tangan mahasiswa yang dibubuhkan pada saat pelaksanaan ujian.

* Tabel TranskripNilai.dbf, Tabel ini merupakan tabel kumpulan nilai perolehan mahasiswa dari setiap mata kuliah dari semester awal sampai semester akhir

\begin{tabular}{|l|l|l|l|}
\hline Nama Field & Nipe Data & 12 & Primary Key \\
\hline NPM & Character & 30 & \\
\hline ProgramStudi & Numeric & 1 & \\
\hline Jenjang & Character & 2 & \\
\hline KodeMK & Character & 10 & \\
\hline NamaMK & Character & 30 & \\
\hline SKS & Numeric & 1 & \\
\hline HM & Character & 1 & \\
\hline AM & Numeric & 1 & \\
\hline M & Numeric & 2 & \\
\hline Ket & Character & 10 & \\
\hline Jumlah & Numeric & 3 & \\
\hline IPK & Numeric & 4 & \\
\hline TanggalLulus & DateTime & 8 & \\
\hline JudulSkripsi/TA & Character & 150 & \\
\hline Tanggal & DateTime & 8 & \\
\hline
\end{tabular}

Tabel 9 : Tabel TranskrpNilia.dbf

Keterangan :

> TanggalLulus adalah tanggal pada saat sidang skripsi/TA mahasiswa tersebut;

$>$ JudulSkripsi/TA adalah judul skripsi/TA mahasiswa tersebut;

Tanggal adalah tanggal pada saat mencetak transkrip.

* Tabel Pendukung, Untuk mendukung program maka ditambahkan 3 buah tabel yaitu:

1. Tabel untuk mencatat tanggal dan waktu user masuk dan keluar dari sistem aplikasi; 
2. Tabel untuk menyimpan perubahan konfigurasi dari icon, mouse, background dan simbol dalam laporan;

3. Tabel untuk memberikan hak akses kepada user, sehingga dapat memasuki sistem aplikasi. Tabel ini dibuat merupakan tabel untuk mendukung keamanan sistem yang berisi user name dan password yang sudah dikodekan.

* Relationship/Hubungan antar tabel, Dari uraian diatas dapat digambarkan hubungan antar tabel seperti pada gambar di bawah ini:

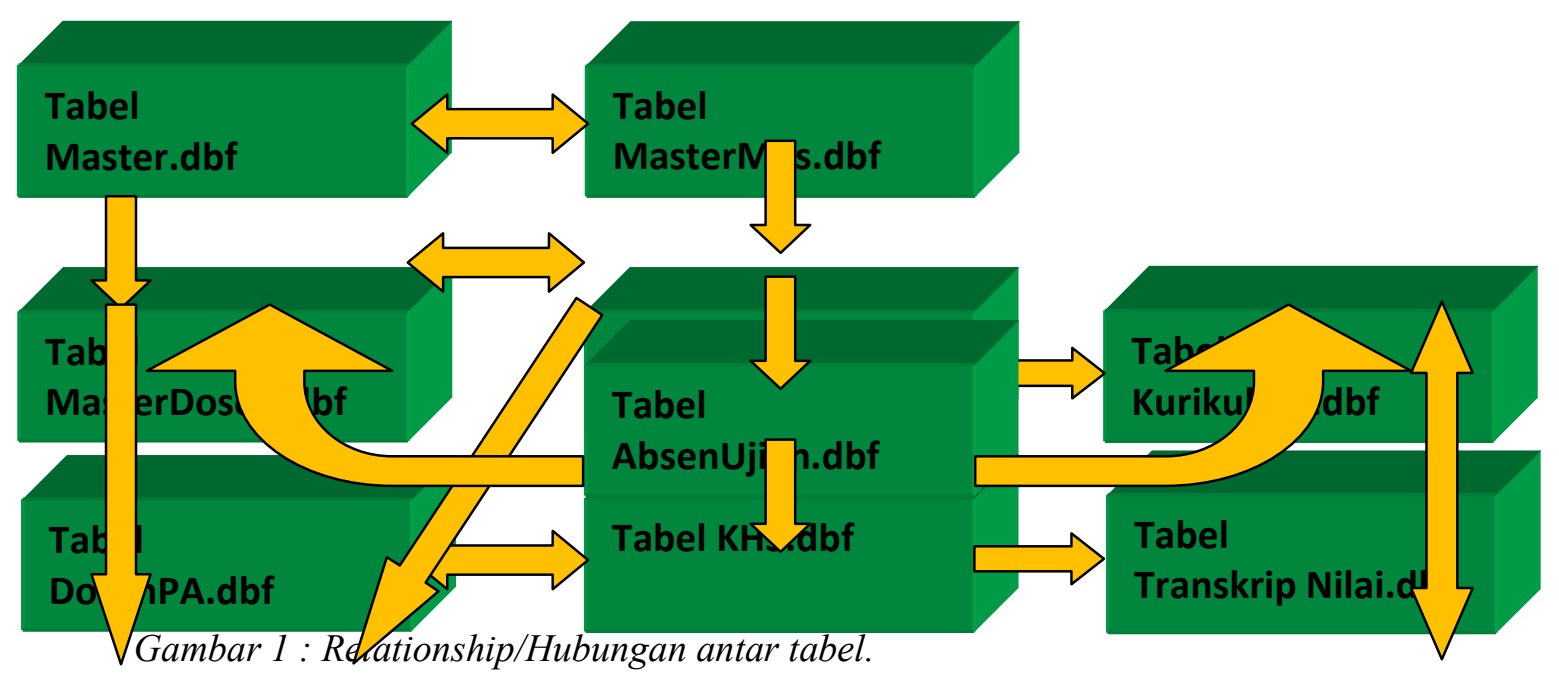

Dari gambar di atas terlihat bahwa rancangan sistem administrasi akademik yang dibuat merupakan hubungan antar tabel yang mempunyai keterkaitan satu dengan lainnya, dengan adanya sistem adminstrasi akademik berbasis komputer akan mempermudah proses kegiatan akademik yang diselenggarakan, sehingga kegiatan akademik tersebut dapat berjalan dengan efektif dan efisien serta apa yang direncanakan dapat berjalan sesuai dengan waktu yang telah ditetapkan.

\section{Kesimpulan dan Saran}

Dari hasil penelitian diatas dapat diambil beberapa kesimpulan antara lain; (a) Sistem Adminstrasi Akademik Sekolah Tinggi Ilmu Manajemen Sukma Medan masih dilakukan secara manual sehingga kegiatan akademik sedikit terganggu, dan rencana waktu yang telah ditetapkan mengalami keterlambatan, (b) Rancangan sistem administrasi akademik yang dibuat merupakan hubungan antar tabel yang mempunyai keterkaitan satu dengan lainnya, dengan adanya sistem adminstrasi akademik berbasis komputer akan mempermudah proses kegiatan akademik yang diselenggarakan, sehingga kegiatan akademik tersebut dapat berjalan dengan efektif dan efisien serta apa yang direncanakan dapat berjalan sesuai dengan waktu yang telah ditetapkan.

Sedangkan saran dari penelitian ini yaitu: (a) Selain peningkatan pengolahan data dengan sistem adminstrasi yang berbasiskan komputer, sumber daya pemakai (brainware) juga harus ditingkatkan untuk menunjang dalam pengoperasian sistem administrasi yang akan dipakai, (b) Sistem administrasi secara global akan lebih dapat bermanfaat daripada terbatas 
pada lingkup tertentu. Dengan adanya sistem administrasi berbasis komputer diharapkan dapat diperluas lagi dengan memakai media internet sehingga informasi yang tersebar menjadi lebih luas dan bermanfaat.

\section{Daftar Pustaka}

Chusing Berry E, 2000, Sistem Informasi Manajemen dan Organisasi Perusahaan, Terjemahan Ruchyat Kosasih, Erlangga, Jakarta.

Davis Gordon B, 2004, Kerangka Dasar Sistem Informasi Manajemen, Bagian I, Pengantar Seni Manajemen, Jakarta.

H.M., Jogiyanto, 2000, Analisis dan Desain Sistem Informasi: Pendekatan Terstruktur, Andi Offset Yogyakarta.

Harso Wardhinata dan Supran Nasution, 2003, Komputer dan Sistem Informasi Manajemen, Erlangga, Jakarta.

J. Supranto, MA, 2000, Teknik Sampling untuk Survei \& Eksperimen, Rineka Cipta, Jakarta.

Jogiyanto, 2003, Sistem Informasi Manajemen, Erlangga, Jakarta

Kurweni Ukar, 2001, Visual Basic untuk Pemula, PT. Komputindo, Jakarta.

Kurweni Ukar, 2004, Visual Basic untuk Lanjutan, PT. Komputindo, Jakarta.

Longkutoy Jhon J, 2003, Pengantar Komputer, Cetakan Kesepuluh, Mitra Sumber Widya, Jakarta.

Moekjat, 2003, Sistem Informasi Manajemen, Erlangga, Jakarta.

Murdick Arikunto, 2004, Sistem Informasi Manajemen, Erlangga, Jakarta.

Nia Kumaladewi, Dewi Agushinta R, Studi Rancangan Sistem Informasi Pembuatan kartu rencana studi (KRS) Online di STMIK-LPMIK, http://dewiar.staff.gunadarma.ac.id/Downloads/files/706/StudiKasusAPS.pdf, dikunjungi 6 April 2009.

Raymond McLeod, Jr., 2001, Management information System, 5th, Macmillan Publishing Company, New York.

Syafrizal Helmi, Penerapan Sistem Informasi Manajemen pada Perguruan Tinggi, Makalah disampaikan pada Pelatihan Pengembangan Sistem Informasi Manajemen Pendidikan Tinggi bagi Dosen Swasta di Lingkungan Kopertis Wilayah I, 2007. 